\title{
DETERMINAN RETURN SAHAM SYARIAH DENGAN RISIKO SISTEMATIS SEBAGAI VARIABEL MEDIASI
}

\author{
Irman Firmansyah \\ Program Studi Akuntansi Fakultas Ekonomi Universitas Siliwangi \\ Jl. Siliwangi No. 24 Tasikmalaya Jawa Barat 46115
}

\begin{abstract}
Islamic capital market is the investment alternatives in accordance with Islamic law. However, the purpose of investing is to obtain a high return stock. This study aimed to analyze the fundamental factors in predicting stock return of sharia with systematic risk as a mediating variable. Fundamental factors measured by DER, EPS, ROA, PER and NPM and systematic risk measured by beta. Data taken from the Islamic capital market through the Jakarta Islamic Index (JII) in a span of research in 2013 and 2014. The analysis used is multiple regression analysis and Sobel test. The results showed that DER and PER positive effect on sharia stock return, beta negative effect on sharia stock return and EPS, ROA and NPM no effect on sharia stock return. Whereas in mediating variable testing, the beta did not mediate the relationship between DER, EPS, ROA, NPM and PER to sharia stock return.
\end{abstract}

Keywords: sharia stock return, fundamental factor, systematic risk, multiple regression analysis, sobel test

\section{PENDAHULUAN}

Peran serta pasar modal dalam memajukan perekonomian suatu negara sangat besar karena dapat membantu perusahaan dalam memperoleh dana segar guna menjaga likuiditasnya. Selain itu keberadaannya juga membantu masyarakat yang akan menginvestasikan uangnya melalui berbagai jenis instrumen keuangan. Menurut Jusmaliani (2008) investasi merupakan kegiatan muamalah yang sangat dianjurkan, karena dengan berinvestasi harta yang dimiliki menjadi lebih produktif dan juga mendatangkan manfaat bagi orang lain.
Di Indonesia tidak hanya pasar modal yang beroperasi secara konvensional namun berdiri pula pasar modal syariah yang tentunya berbeda karakteristik karena pada pasar modal syariah lebih mengutamakan prinsip-prinsip Islam agar para pemodal yang ingin bertransaksi secara syariah mempunyai wadah yang lebih cocok untuk kepentingannya.

Pada awalnya keberadaan pasar modal syariah ditujukan untuk menyelamatkan perusahaan yang sedang terancam likuiditasnya sehingga membutuhkan dana segar dengan sangat cepat, begitupun

Korespondensi dengan Penulis:

Irman Firmansyah HP: +6281223271111

e-mail: irmanfirmansyah@unsil.ac.id 
dari pihak masyarakat pemodal sangat membantu yang kelebihan dana untuk diinvestasikan pada tempat yang cocok. Salah satu produk pada pasar modal syariah yaitu saham syariah. Saham syariah merupakan salah satu bentuk dari saham biasa yang memiliki karakteristik khusus berupa kontrol yang ketat dalam hal kehalalan ruang lingkup kegiatan usaha. Sebagian saham syariah dimasukkan dalam perhitungan Jakarta Islamic Index (JII), yang merupakan indeks yang dikeluarkan oleh PT. Bursa Efek Indonesia yang merupakan subset dari Indeks Harga Saham Gabungan (IHSG) (Auliyah \& Hamzah, 2006).

Pada praktiknya, saham syariah di pasar modal syariah hampir sama dengan di pasar modal konvensional karena tujuan dari investasi adalah memperoleh keuntungan dengan dihadapkan pada suatu resiko. Semakin besar return yang diharapkan maka semakin besar pula resiko yang dihadapi. Hal ini diakibatkan dari faktor-faktor yang mempengaruhi return saham syariah itu sendiri khususnya faktor internal perusahaan atau sering disebut faktor fundamental. Diantara faktor-faktor yang diprediksi berpengaruh terhadap return saham yaitu DER, EPS, ROA, NPM dan PER. Hasil Penelitian Santosa (2011), Arista (2012) serta Chuzaimah dan Amalina (2014) menemukan DER berpengaruh terhadap return saham, sedangkan penelitian Saribu (2011), Hijriah (2007) dan Harahap (2001) menemukan DER tidak berpengaruh terhadap return saham. Hasil penelitian Widodo (2007) dan Aulianisa (2013) menemukan EPS berpengaruh terhadap return saham, sedangkan penelitian Auliyah dan Hamzah (2006) dan Hijriah (2007) menemukan bahwa EPS tidak berpengaruh terhadap return saham. Hasil penelitian Chuzaimah dan Amalina (2014) menemukan ROA berpengaruh terhadap return saham sedangkan hasil penelitian Aulianisa (2013) menemukan bahwa ROA tidak berpengaruh terhadap return saham. Hasil penelitian Aulianisa (2013) menemukan bahwa PER berpengaruh terhadap return saham. Hasil penelitian Christanty (2009) dan Harjito dan Aryayoga (2009) menemukan bahwa NPM berpengaruh negatif terhadap return saham, sedangkan Aulianisa (2013) menyimpulkan bahwa NPM tidak berpengaruh terhadap return saham.

Selain variabel-variabel di atas, beta yang merupakan cerminan dari risiko sistematis suatu investasi saham diprediksi pula dapat berpengaruh terhadap return saham. Hal ini sesuai dengan beberapa hasil penelitian sebelumnya diantaranya yaitu Al-Rjoub, et al. (2010) dan Al-Qudah \& Laham (2013), Rachmatika (2006), Asma (2006) dan Utomo (2007) yang menunjukkan adanya hubungan yang signifikan antara risiko sistematis dan return saham. Akan tetapi posisi beta pada penelitian ini yaitu sebagai variabel mediasi antara variabel independen dengan return saham sebagai variabel dependen. Hal ini dikarenakan beta dapat dipengaruhi pula oleh variabel DER, EPS, ROA, NPM dan PER.

Namun demikian masih dibutuhkan kejelasan mengenai keterkaitan antara ketiga komponen variabel di atas yaitu variabel independen (DER, EPS, ROA, NPM dan PER), variabel mediasi (beta) dan variabel dependen (return saham) khususnya pada pasar modal syariah sehingga dibutuhkan analisis yang lebih lanjut untuk memperoleh penemuan yang terbaru.

\section{HIPOTESIS \\ Debt to Equity Ratio (DER)}

Debt to Equity Ratio (DER) merupakan rasio solvabilitas yang mengukur kemampuan kinerja perusahaan dalam mengembalikan hutang jangka panjangnya dengan melihat perbandingan antara total hutang dengan total ekuitasnya (Ang, 1997). Rasio ini dapat memberikan gambaran mengenai struktur modal yang dimiliki oleh perusahaan sehingga dapat dilihat tingkat risiko tidak terbayarkan suatu hutang (Suharli, 2005). Hasil Penelitian Santosa (2011), Arista (2012) dan Chuzaimah dan Amalina (2014) menemukan DER berpengaruh 


\section{Jurnal Keuangan dan Perbankan | KEUANGAN}

Vol. 20, No.3, September 2016: 358- 368

terhadap return saham. Artinya semakin besar rasio DER maka return saham akan semakin besar pula, hal ini terjadi karena investor menilai bahwa jika perusahaan memiliki hutang banyak berarti telah dipercaya oleh pihak ketiga atas kekuatan cashflownya dalam mengembalikan pinjamannya karena semakin banyak utang maka menandakan usaha sedang dalam tahap peningkatan. Oleh karena itu berdasarkan hasil penelitian tersebut maka hipotesis yang diambil yaitu:

$\mathrm{H}_{1}$ : DER berpengaruh positif terhadap return saham syariah

\section{Earning Per Share (EPS)}

Earning per Share (EPS) merupakan perbandingan antara laba bersih dengan jumlah saham beredar. EPS menunjukkan keberhasilan perusahaan dalam memperoleh laba dari setiap sahamnya atas operasional pada suatu periode. Secara langsung EPS dipengaruhi oleh pendapatan perusahaan sehingga jika rasio EPS tinggi maka berdampak pada peningkatan return saham, karena investor akan menilai bahwa perusahaan dalam keadaan baik. Hasil penelitian Widodo (2007) dan Aulianisa (2013) menunjukan EPS berpengaruh terhadap return saham. Oleh karena itu hipotesis yang diambil adalah:

$\mathrm{H}_{2}$ : EPS berpengaruh positif terhadap return saham syariah

\section{Return On Asset (ROA)}

Return On Asset (ROA) adalah rasio yang mengukur kemampuan perusahaan dalam memperoleh laba bersih berdasarkan tingkat aset yang dimiliki. Jika ROA tinggi maka kinerja perusahaan dalam keadaan baik dan pada akhirnya investor akan tertarik. Sehingga jika ROA tinggi maka return saham akan tinggi pula. Hasil penelitian Chuzaimah dan Amalina (2014) menyimpulkan bahwa ROA berpengaruh terhadap return saham. Oleh karena itu hipotesis yang diambil adalah:
$\mathrm{H}_{3}$ : ROA berpengaruh positif terhadap return saham syariah

\section{Net Profit Margin (NPM)}

Net Profit Margin (NPM) adalah rasio yang digunakan untuk mengukur kemampuan perusahaan dalam menghasilkan laba atas dari penjualan yang diperolehnya selama satu periode. NPM dihitung dengan membagi laba bersih dengan total penjualan. Sehingga jika rasio ini tinggi maka menunjukkan kinerja perusahaan yang baik. oleh karena itu akan menarik investor untuk menanamkan modalnya yang pada akhirnya akan meningkatkan return saham. Hasil penelitian Christanty (2009) dan Harjito dan Aryayoga (2009) menyimpulkan bahwa NPM berpengaruh negatif terhadap return saham. Oleh karena itu hipotesis yang diambil adalah:

$\mathrm{H}_{4}$ : NPM berpengaruh positif terhadap return saham syariah

\section{Price Earning Ratio (PER)}

Price Earning Ratio (PER) merupakan rasio antara harga saham dengan pendapatan setiap lembar saham. Rasio ini menggambarkan keuntungan yang diperoleh perusahaan (emiten) terhadap sahamnya. Hasil penelitian Aulianisa (2013) menyimpulkan bahwa PER berpengaruh terhadap return saham. Jika rasio PER besar maka kecenderungan tidak disukai oleh investor konvensional karena tingkat pengembalian yang akan lama dan dalam jangka pendek keuntungan yang diperoleh tidak terlalu besar atau return yang diperoleh adalah sedikit. Akan tetapi investasi pada saham syariah adalah sebaliknya harus diniatkan investasi dalam jangka panjang guna menghindari riba. Sehingga rasio PER yang tinggi akan meningkatkan return saham syariah. Oleh karena itu itu hipotesis yang diambil yaitu:

$\mathrm{H}_{5}$ : PER berpengaruh positif terhadap return saham syariah 


\section{Risiko Sistematis (Beta)}

Risiko sistematis dapat diproksi dengan beta saham sekuritas bersangkutan. Beta suatu sekuritas menunjukkan kepekaan tingkat keuntungan suatu sekuritas terhadap perubahan pasar (Warsito dkk, 2003). Beta dapat dihitung dengan data historis yaitu dengan menggunakan data pasar, data akuntansi maupun data fundamental (Jogiyanto, 2010: 377). Sehingga beta saham dengan cara menghitung dari data yang dihasilkan dari laporan keuangan. Semakin tinggi resiko saham maka akan mempengaruhi penurunan return saham karena investor makin hati-hati untuk berinvestasi. Hal ini telah dibuktikan oleh hasil penelitian Al-Rjoub, et al. (2010) dan Al-Qudah \& Laham (2013), Rachmatika (2006), Asma (2006) dan Utomo (2007) yang menunjukkan hubungan yang signifikan secara statistik antara risiko sistematis dan return saham. Oleh karena itu hipotesis yang diambil yaitu:

$\mathrm{H}_{6}$ : Beta berpengaruh negatif terhadap return saham syariah

\section{Resiko Sistematis dalam hubungan antara variabel independen dengan variabel dependen}

Selain sebagai variabel yang mempengaruhi return saham, beta juga dipengaruhi oleh variabel independen lainnya yaitu DER, EPS, ROA, NPM dan PER seperti hasil penelitian yang dilakukan oleh Hamada (1972), Bowman (1979) dan Hamzah (2005) menunjukkan ada hubungan antara DER (leverage) dengan resiko sistematik, penelitian Mediati (2008) menunjukkan hubungan antara tingkat pengembalian (EPS) dengan resiko yang melekat pada saham, penelitian Tendelilin (1997) dan Hamzah (2005) menunjukkan ada hubungan antara profitabilitas dengan beta, penelitian Julduha dan Kusumawardhani (2013) yang menunjukkan NPM berpengaruh negatif terhadap beta saham dan penelitian Agustina (2007) yang menun- jukkan PER berpengaruh terhadap beta saham. Oleh karena itu posisi beta adalah sebagai variabel mediasi (perantara) antara DER, EPS, ROA, NPM dan PER dengan return saham. Berangkat dari hasil penelitian tersebut, maka hipotesis yang diambil yaitu:

$\mathrm{H}_{7}$ : Beta memediasi hubungan antara DER dengan return saham syariah

$\mathrm{H}_{8}$ : Beta memediasi hubungan antara EPS dengan return saham syariah

$\mathrm{H}_{9}$ : Beta memediasi hubungan antara ROA dengan return saham syariah

$\mathrm{H}_{10}$ : Beta memediasi hubungan antara NPM dengan return saham syariah

$\mathrm{H}_{11}$ : Beta memediasi hubungan antara PER dengan return saham syariah

\section{METODE}

Populasi yang digunakan dalam penelitian ini adalah perusahaan yang terdaftar di Jakarta Islamic Index yaitu sebanyak 30 perusahaan per periode pada tahun 2013 dan 2014. Data diambil dari website www.idx.co.id.

Teknik analisis data dalam penelitian ini dibagi 2 tahap yaitu:

1. Analisis Regresi Berganda

Pada tahap ini akan dilakukan analisis regresi berganda dengan menggunakan IBM SPSS ver. 22. untuk menguji pengaruh variabel independen (DER, EPS, ROA, NPM dan PER) terhadap variabel dependen (return saham syariah). Pada analisis ini terlebih dahulu dilakukan uji kualitas data untuk memastikan data layak dilakukan analisis regresi. Pengujian dilakukan melalui uji asumsi klasik yang terdiri dari uji normalitas, uji autokorelasi, uji heteroskedastisitas dan uji multikolinieritas.

Berikut adalah persamaan regresinya:

Return $=\mathrm{a}+\mathrm{b}_{1}$ DER $+\mathrm{b}_{2}$ EPS $+\mathrm{b}_{3} \mathrm{ROA}+\mathrm{b}_{4}$ $\mathrm{NPM}+\mathrm{b}_{5}$ PER + $\mathrm{b}_{6}$ BETA + e............ 


\section{Jurnal Keuangan dan Perbankan | KEUANGAN}

Vol. 20, No.3, September 2016: 358- 368

2. Analisis Jalur (Sobel Test)

Pada tahap ini akan dilakukan analisis mengenai beta sebagai variabel mediasi antara pengaruh variabel independen (DER, EPS, ROA, NPM dan PER) terhadap variabel dependen yaitu return saham syariah. Analisis dilakukan melalui sobel test dengan menggunakan IBM SPSS ver. 22.

Berikut adalah persamaan regresinya:

BETA $=\mathrm{a}+\mathrm{bDER}+\mathrm{e} \%$ Return $=\mathrm{a}+\mathrm{b}_{1}$ DER + $\mathrm{b}_{6}$ BETA + e

BETA $=a+b E P S+e \%$ Return $=a+b_{2}$ EPS $+b_{6}$ BETA + e

BETA $=a+b R O A+e \%$ Return $=a+b_{3}$ ROA + $\mathrm{b}_{6}$ BETA + e..........

$\mathrm{BETA}=\mathrm{a}+\mathrm{bNPM}+\mathrm{e} \%$ Return $=\mathrm{a}+\mathrm{b}_{4} \mathrm{NPM}$

$+\mathrm{b}_{6}$ BETA + e.........

BETA $=a+b$ PER + e $\%$ Return $=a+b_{5}$ PER + $b_{6}$ BETA + e...........

Dimana:

$\mathrm{a}=$ Konstanta, $\mathrm{b}_{1,2,3,5,6}=$ Koefisien Regresi, Return=Return Saham Syariah, DER=Debt to Equity Ratio, EPS=Earning Per Share, ROA=Return On Asset, NPM=Net Profit Margin, PER=Price Earning Ratio, BETA= Beta Saham Syariah, e=residu

\section{HASIL}

Data yang berhasil dikumpulkan yaitu sebanyak 60 observasi untuk 2 periode penelitian sesuai dengan jumlah populasi pada Jakarta Islamic Index (JII) yaitu sebanyak 30 perusahaan setiap periodenya. Selanjutnya data yang telah terkumpul dianalisis kualitasnya agar memenuhi persyaratan dilakukan uji regreasi melalui uji asumsi klasik yang terdiri dari uji normalitas, uji autokorelasi, uji heteroskedastisitas dan uji multikolinieritas, sehingga data yang lolos pengujian dan siap dianalisis regresi menjadi 51 observasi.

Tabel 1 menyajikan resume hasil pengujian kualitas data dengan IBM SPSS dengan penjelasan sebagai berikut:

1. Uji normalitas. Model regresi yang baik adalah yang memiliki distribusi normal atau mendekati normal. Pengujian distribusi normal dilakukan dengan uji Kolmogorov-Smirnov. Jika nilai Asymp. Sig (2-tailed) lebih besar dari 0,05, maka data dinyatakan berdistribusi normal. Hasil uji normalitas (Kolmogorov Smirnov) menunjukkan nilai Asymp. Sig (2-tailed) yaitu 0,844. Nilai ini lebih besar dari 0,05 atau $5 \%$. Sehingga dapat disimpulkan bahwa data dinyatakan berdistribusi normal.

Tabel 1. Uji Asumsi Klasik

\begin{tabular}{|c|c|c|c|c|}
\hline \multicolumn{5}{|c|}{ Pengujian Asumsi Klasik } \\
\hline Kolmogorov-Smirnov Test & \multicolumn{2}{|c|}{ Asymp. Sig. (2-tailed) } & \multicolumn{2}{|l|}{0,844} \\
\hline Durbin Watson & & & \multicolumn{2}{|l|}{2,033} \\
\hline \multirow[t]{6}{*}{ Glejser Test } & \multicolumn{2}{|l|}{ Sig. DER } & \multicolumn{2}{|l|}{0,070} \\
\hline & \multicolumn{2}{|l|}{ EPS } & \multicolumn{2}{|l|}{0,283} \\
\hline & \multicolumn{2}{|l|}{$\mathrm{ROA}$} & \multicolumn{2}{|l|}{0,555} \\
\hline & \multicolumn{2}{|l|}{ NPM } & \multicolumn{2}{|l|}{0,380} \\
\hline & \multicolumn{2}{|l|}{ PER } & \multicolumn{2}{|l|}{0,084} \\
\hline & \multicolumn{2}{|l|}{ BETA } & \multicolumn{2}{|l|}{0,422} \\
\hline \multirow[t]{6}{*}{ Collinearity Statistics } & VIF. DER & 1,068 & TOL. DER & 0,936 \\
\hline & EPS & 1,075 & EPS & 0,931 \\
\hline & $\mathrm{ROA}$ & 6,257 & $\mathrm{ROA}$ & 0,160 \\
\hline & NPM & 6,220 & NPM & 0,161 \\
\hline & PER & 1,120 & PER & 0,893 \\
\hline & BETA & 1,111 & BETA & 0,900 \\
\hline
\end{tabular}


2. Uji autokorelasi. Uji ini bertujuan untuk menguji korelasi antara kesalahan pengganggu pada periode $\mathrm{t}$ dengan kesalahan periode $\mathrm{t}-1$ (sebelumnya). Jika terjadi korelasi, maka dinamakan ada problem autokorelasi. Autokorelasi muncul karena observasi yang berurutan sepanjang waktu berkaitan satu sama lainnya. Model regresi yang baik adalah yang bebas dari autokorelasi (Ghozali, 2006). Berdasarkan hasil analisis nilai Durbin Watson (DW) sebesar 2,033. Sedangkan berdasarkan tabel Durbin Watson (DW) dengan $\mathrm{k}=6$ dan $\mathrm{n}=51$ maka nilai $\mathrm{dL}=1,3000$ dan $\mathrm{dU}=1,8201$, maka 4$\mathrm{dU}=2,1799$ dan $4-\mathrm{dL}=2,7000$. Oleh karena itu nilai DW berada di antara dU dan 4-dU, daerah ini merupakan daerah yang tidak terjadi autokorelasi.

3. Uji heteroskedastisitas. Uji ini digunakan untuk mengetahui ada atau tidaknya ketidaksamaan varian dari residual pada model regresi (Priyatno, 2008). Prasyarat yang harus terpenuhi dalam uji ini adalah tidak adanya masalah heteroskedastisitas. Untuk mendeteksi ada tidaknya heteroskedastisitas maka digunakan Uji Glejser. Dari tabel 1 diketahui bahwa nilai sig. semua variabel independen lebih dari besar dari 0,05. Hal ini berarti tidak terjadi gejala heteroskedastisitas pada model regresi.

4. Uji multikolinieritas. Uji ini dapat dilakukan dengan matriks korelasi dengan melihat besarnya nilai VIF (variance inflation factor) dan tolerance. Suatu model regresi yang bebas dari multikolinearitas memiliki angka VIF di sekitar kurang dari angka 10 dan angka tolerance lebih besar dari 0,1. Hasil pengujian menunjukkan bahwa nilai VIF dari masing-masing variabel independen kurang dari angka 10 dan nilai tolerance (TOL) yang diperoleh menunjukkan lebih dari angka 0,1. Dari hasil tersebut dapat diketahui bahwa model regresi terbebas dari multikolonieiritas antar variabel independen.

\section{Analisis Regresi Berganda}

Setelah pengujian asumsi klasik selesai dan dinyatakan bahwa kualitas data adalah baik, selanjutnya dilakukan analisis regresi berganda, dengan terlebih dahulu menguji ketepatan model (uji F).

Tabel 2. Hasil Perhitungan Uji F dan Uji t

\begin{tabular}{cclrr}
\hline $\mathrm{F}$ & Sig. & Variabel & \multicolumn{1}{c}{ T } & \multicolumn{2}{c}{ Sig. } \\
\hline 9,6683 & .000 & DER & 3,135 &, 003 \\
& & EPS &,- 244 &, 809 \\
& & ROA & 1,048 &, 300 \\
& NPM & $-1,107$ &, 274 \\
& & PER & 6,456 &, 000 \\
& & BETA & $-1,732$ &, 090 \\
\hline
\end{tabular}

Sumber: Output IBM SPSS, data diolah

Berdasarkan tabel 1 diperoleh hasil bahwa nilai signifkansi uji $\mathrm{F}$ yaitu 0,000 (lebih kecil dari batas nilai signifkansi, $\alpha=0,05$ ) sehingga model dikatakan baik dan layak untuk dilakukan analisis uji t. Dari hasil pengujian dengan menggunakan alat analisis regresi berganda diperoleh hasil analisis sebagai berikut:

Variabel pertama yaitu debt to equity ratio (DER). Hasil analisis diperoleh nilai signifikansi variabel DER yaitu sebesar 0,003 dengan koefisien positif, dapat disimpulkan bahwa DER berpengaruh positif terhadap return saham syariah sehingga hipotesis pertama diterima. Variabel kedua yaitu earning per share (EPS). Hasil analisis diperoleh nilai signifikansi variabel EPS yaitu sebesar 0,809 dengan koefisien negatif, dapat disimpulkan bahwa EPS tidak berpengaruh terhadap return saham syariah sehingga hipotesis kedua ditolak. Variabel ketiga yaitu return on asset (ROA). Hasil analisis diperoleh nilai signifikansi variabel ROA yaitu sebesar 0,300 dengan koefisien positif, dapat disimpulkan bahwa ROA tidak berpengaruh terhadap return saham syariah sehingga hipotesis ketiga ditolak. Variabel keempat yaitu net profit margin (NPM). Hasil analisis diperoleh nilai signifikansi variabel NPM yaitu sebesar 0,274 de- 


\section{Jurnal Keuangan dan Perbankan | KEUANGAN}

Vol. 20, No.3, September 2016: 358- 368

ngan koefisien negatif, dapat disimpulkan bahwa NPM tidak berpengaruh terhadap return saham syariah sehingga hipotesis keempat ditolak. Variabel kelima yaitu price earning ratio (PER). Hasil analisis diperoleh nilai signifikansi variabel PER yaitu sebesar 0,000 dengan koefisien positif, dapat disimpulkan bahwa PER berpengaruh positif terhadap return saham syariah sehingga hipotesis kelima dapat diterima. Variabel keenam yaitu beta. Hasil analisis diperoleh nilai signifikansi variabel beta yaitu sebesar 0,090 dengan koefisien negatif, dapat disimpulkan bahwa beta berpengaruh negatif terhadap return saham syariah pada level $10 \%$ sehingga hipotesis keenam diterima.

\section{Analisis Jalur (Sobel Test)}

Langkah selanjutnya yaitu analisis jalur dalam rangka menguji beta sebagai variabel mediasi antara variabel independen (DER, EPS, ROA, NPM dan PER) terhadap variabel dependen (return saham syariah), maka dilakukan dengan menggunakan sobel test dan bootstraping. Berdasarkan hasil pengujian dengan menggunakan IBM SPSS ver. 22 diperoleh output yang disajikan pada tabel 3:

Tabel 3. Hasil Perhitungan Sobel Test

\begin{tabular}{ccc}
\hline $\begin{array}{c}\text { Variables In Simple } \\
\text { Mediation Model }\end{array}$ & $\mathrm{Z}$ & Sig (two) \\
\hline Y (RETURN) & $-1,1041$ & 0,2696 \\
X (DER) & & \\
M (BETA) & & \\
\hline Y (RETURN) & 0,5569 & 0,5776 \\
X (EPS) & & \\
M (BETA) & & \\
\hline Y (RETURN) & 0,3442 & 0,7307 \\
X (ROA) & & \\
M (BETA) & & \\
Y (RETURN) & 0,3998 & 0,6893 \\
X (NPM) & & \\
M (BETA) & & \\
\hline Y (RETURN) & 0,8478 & 0,3966 \\
X (PER) & & \\
M (BETA) & & \\
\hline Sumber: Output IBM SPSS, data diolah
\end{tabular}

Tabel 3 merupakan ringkasan hasil olahan output sobel test mengenai pengujian variabel mediasi sehingga dapat dilihat nilai signifikansinya untuk menentukan ada atau tidak pengaruh. Nilai signifikansi diambil dari output "Indirect Effect And Significance Using Normal Distribution". Jika nilai signifikansi kurang dari 0,05 maka variabel beta merupakan variabel mediasi dan sebaliknya.

Dari pengujian sobel test yang disajikan pada tabel 3, tidak ada satu pun nilai signifikansi yang kurang dari 0,05 sehingga dapat disimpulkan bahwa beta tidak memediasi hubungan antara DER, EPS, ROA, NPM dan PER terhadap return saham syariah. Oleh karena itu hipotesis 7 sampai 11 ditolak.

\section{PEMBAHASAN}

Hasil penelitian membuktikan bahwa DER berpengaruh positif terhadap return saham syariah, artinya rasio DER yang tinggi menunjukkan bahwa perusahaan dalam keadaan performa yang membaik khususnya dalam jangka panjang. Hal ini dikarenakan pihak ketiga yang meminjamkan dana ke perusahaan telah memiliki kepercayaan yang baik atas kemampuannya mengembalikan pinjaman karena performa perusahaan sedang meningkat. Apalagi ketatnya seleksi pada perusahaan yang masuk dalam JII membuat kreditor semakin percaya atas kinerja emiten. Oleh karena itu pada akhirnya semakin tinggi rasio DER maka akan meningkatkan return saham syariah. Hasil ini sejalan dengan penelitian Santosa (2011), Arista (2012) dan Chuzaimah dan Amalina (2014) yang menunjukkan adanya pengaruh antara DER terhadap return saham.

Hasil analisis lainnya menunjukkan bahwa EPS tidak berpengaruh terhadap erturn saham syariah, artinya bahwa EPS bukanlah faktor yang membuat investor tertarik untuk menanamkan modalnya, karena emiten yang ada pada JII sangat beragam sehingga emiten mempunyai karekteristik 
yang bermacam-macam mengenai perolehan laba. Bahkan besarnya EPS tergantung dari jumlah saham yang diedarkan, semakin banyak saham yang beredar maka EPS dapat bernilai kecil meski labanya besar. Oleh karena itu EPS bukan menjadi suatu penilaian investor dalam berinvestasi di pasar modal syariah. Hasil ini sesuai dengan hasil penelitian Auliyah dan Hamzah (2006) dan Hijriah (2007) bahwa EPS tidak berpengaruh terhadap return saham.

Selanjutnya penelitian ini menemukan bahwa ROA tidak berpengaruh terhadap return saham syariah. Keadaan ini dapat disebabkan karena ROA merupakan analisis keuangan yang masih menyimpan ketidakpastian jumlah laba, karena laba yang tinggi belum tentu memberikan nilai ROA yang tinggi jika aset yang dimilikinya sangat besar begitupun sebaliknya. Oleh karena itu ROA belum mampu memprediksi return saham syariah, sehingga masih membutuhkan analisis rasio-rasio keuangan yang lainnya. Pada akhirnya investor tidak terlalu memberikan respon yang terlalu besar atas keadaan ROA emiten yang ada di pasar modal syariah. Hasil ini sesuai dengan hasil penelitian Aulianisa (2013) bahwa ROA tidak berpengaruh terhadap return saham.

Hasil analisis selanjutnya yaitu NPM tidak berpengaruh terhadap return saham syariah. Keadaan ini menunjukkan bahwa para investor masih menghindari rasio-rasio keuangan yang belum memberikan kepastian laba. Sama seperti pada ROA, NPM pun belum menunjukkan kepastian laba karena laba yang tinggi belum mampu digambarkan dengan NPM yang tinggi. Jika laba yang diperoleh besar akan tetapi penjualan besar pula maka rasio NPM akan tetap kecil sehingga NPM tidak menggambarkan laba yang diperoleh. Oleh karena itu besar kecilnya NPM belum mampu memprediksi return saham syariah sehingga investor belum tertarik untuk menentukan investasinya dilihat dari rasio NPM. Hasil ini sesuai dengan penelitian Aulianisa (2013) yang menyimpulkan bahwa NPM tidak berpengaruh terhadap return saham.

Kemudian hasil analisis PER menunjukkan adanya pengaruh positif terhadap return saham syariah. Hasil ini memberikan gambaran bahwa PER yang tinggi berarti harga saham sedang dalam keadaan yang tinggi dan secara otomatis investor akan menilai bahwa performa emiten yang ada di pasar modal syariah sedang baik. Dengan peningkatan performa tersebut maka merupakan suatu sinyal positif bagi investor untuk berinvestasi yang pada akhirnya akan menaikkan return saham syariah. Hasil ini sejalan dengan penelitian Aulianisa (2013) yang menunjukkan adanya pengaruh antara PER terhadap return saham.

Hasil analisis selanjutnya menemukan beta berpengaruh negatif terhadap return saham syariah. Hal ini menunjukkan bahwa investor pasar modal syariah cenderung berhati-hati dengan resiko yang ada pada sekuritas, hal ini menandakan bahwa terdapat kesamaan tujuan baik di pasar modal syariah maupun di pasar modal konvensional yaitu memperoleh keuntungan yang besar dengan meminimalkan risiko yang ada. Sehingga dengan adanya risiko yang tinggi maka investor akan mengurangi investasinya yang pada akhirnya akan menurunkan return saham syariah. Dengan demikian semakin besar risiko maka semakin menurun return saham syariah. Hasil ini sejalan dengan penelitian Al-Rjoub, et al. (2010) dan AlQudah \& Laham (2013), Rachmatika (2006), Asma (2006) dan Utomo (2007) yang menunjukkan adanya hubungan antara risiko sistematis dan return saham.

Sedangkan dalam pengujian variabel mediasi menunjukkan bahwa beta tidak memediasi semua variabel independen terhadap return saham syariah. Artinya tidak ada satu pun variabel independen yang mempengaruhi return saham syariah harus melalui beta terlebih dulu. Ini artinya risiko sistematis yang melekat pada sekuritas di pasar modal syariah bukanlah suatu variabel yang me- 


\section{Jurnal Keuangan dan Perbankan | KEUANGAN}

Vol. 20, No.3, September 2016: 358- 368

nentukan bahwa variabel independen yang diteliti sangat dipengaruhi pula oleh risiko. Oleh karena itu investor akan langsung melihat variabel-variabel independen (DER, EPS, ROA, NPM dan PER) dalam melakukan investasi demi memperoleh return yang besar pada pasar modal syariah.

\section{KESIMPULAN}

Berdasarkan hasil penelitian dapat disimpulkan sebagai berikut:

1. DER dan PER berpengaruh positif terhadap return saham syariah

2. Beta berpengaruh negatif terhadap return saham syariah

3. EPS, ROA dan NPM tidak berpengaruh terhadap return saham syariah

4. Beta tidak memediasi hubungan antara DER, EPS, ROA, NPM dan PER terhadap return saham syariah

\section{SARAN}

Adapun beberapa saran yang dapat penulis sampaikan yaitu:

Bagi emiten di pasar modal syariah hendaknya memperhatikan struktur modal khususnya leverage (DER). Meski rasio ini memberikan dampak baik bagi perusahaan namun resiko finansial (gagal bayar) harus tetap dijaga demi kepercayaan para investor.

Bagi investor, analisis fundamental harus dilakukan secara menyeluruh tidak hanya dilakukan pada beberapa rasio keuangan saja seperti pada hasil penelitian ini yaitu DER dan PER. Karena masih banyak rasio-rasio keuangan yang diprediksi berpengaruh terhadap return saham syariah.

Bagi peneliti selanjutnya, rentang waktu penelitian ini hanya dua tahun sehingga dapat diperpanjang dengan terus mengedepankan data yang paling update. Penelitian ini hanya dilakukan pada pasar modal syariah sehingga penelitian selanjutnya dapat dibandingkan pula dengan penelitian pada pasar modal konvensional untuk mengetahui perbedaan karakteristik faktor fundamental dan risiko sistematis dalam mempengaruhi return saham.

\section{DAFTAR PUSTAKA:}

Agustina, Nila. 2007. Analisis Pengaruh Faktor-Faktor Fundamental terhadap Beta Saham pada Bank-Bank yang Go-Publik di BEJ. Tesis Magister Manajemen Universitas Katolik Widya Mandala Surabaya. Tidak Dipublikasikan

Al-Rjoub, S. AM., Yousef, A.A., dan Ananzeh, I. E. N. 2010. "Beta Wins Again: Case of four Emerging Markets". Journal of Economic Cooperation and Development, Vol. 31 (1), pp:1-16.

Al-Qudah, Anas dan Laham, Mahmoud. 2013. “The Effect of Financial Leverage \& Systematic Risk on Stock Returns in the Amman Stock Exchange". Research Journal of Finance and Accounting, Vol. 4 (6), pp: 136-145.

Asma, Rusdayanti. 2006. "Cross Section Return Saham Dan Kebijakan Moneter". Jurnal Ekonomi dan Kewirausahaan, Vol. 6 (1), pp. 22-35

Arista, Desi. 2012. “Analisis Faktor Faktor Yang Mempengaruhi Return Saham (Kasus Pada Perusahaan Manufaktur yang Go Public di BEI periode tahun 2005 - 2009)". Jurnal Ilmu Manajemen dan Akuntansi Terapan. Vol. 3 (1), Mei 2012

Aulianisa, Fitri. 2013. "Pengaruh Faktor Fundamental dan Risiko Sistematis terhadap Harga Saham di Pasar Modal Syariah (Studi Empiris JII di BEI Tahun 2007-2010)”. La_Riba, Vol. 7 (1). Pp. 85-103

Auliyah, Robiatul dan Hamzah, Ardi. 2006. “Analisa Karakteristik Perusahaan, Industri dan Ekonomi Makro Terhadap Return dan Beta Saham Syariah di Bursa Efek Indonesia". Simposium Nasional Akuntansi IX, Padang.

Bowman, Robert G., 1979. “The Teoritical Relationship Between Systematic Risk and Financial (Accounting) Variable, The Journal of Finance". Vol. 34 (3), June, pp. 617-630 


\section{Determinan Return Saham Syariah dengan Risiko Sistematis sebagai Variabel Mediasi}

Irman Firmansyah

Christanty, Mila. 2009. Analisis Pengaruh Faktor Fundamental dan Economic Value Added (EVA) terhadap Return Saham Studi pada Saham Perusahaan yang tercatat Aktif dalam LQ 45 di BEI Periode 2003-2007. Tesis Magister Manajemen Universitas Diponegoro Semarang. Tidak Dipublikasikan

Chuzaimah dan Amalina, Nur. 2014. “Analisis Pengaruh Faktor-Faktor Fundamental terhadap Return Saham Syariah pada Perusahaan yang tergabung dalam Jakarta Islamic Index (JII) tahun 2007-2011". Seminar Nasional dan Call For Paper (Sancall 2014). Pp. 189-195

Dewan Syariah Nasional Majelis Ulama Indonesia, 2006. Himpunan Fatwa Dewan Syariah Nasional. Ciputat: CV. Gaung Persada

Fahmi, Irham. 2012. Manajemen Investasi: Teori dan Soal Jawab. Jakarta: Salemba Empat

Ghozali, Imam, 2006. Aplikasi Analisis Multivariate Dengan Program SPSS. Semarang: Badan Penerbit Universitas Diponegoro

Hamada, Robert S., 1972. “The Effect of the Firm's Capital Structure on the Systematic Risk of Common Stocks". Journal of Finance, May, pp. 435-451

Hamzah, Ardi. 2005. “Analisa Ekonomi Makro, Industri dan Karakteristik Perusahaan terhadap Beta Saham Syariah". Paper Simposium Nasional Akuntansi 8, Solo, September.

Harahap, Mursal. 2001. Analisis Pengaruh Leverage Keuangan dan Risiko Saham terhadap Return Saham Perusahaan di Bursa Efek Indonesia. Tesis Universitas Indonesia. Jakarta

Harjito, Agus dan Aryayoga, Rangga. 2009. “Analisis Pengaruh Kinerja Keuangan dan Return Saham di Bursa Efek Indonesia". Fenomena. Vol.7.(1), pp. 13-21

Heryawan, Heri. 2013. Analisis Pengaruh Earning Per Share (EPS), Net Profit Margin (NPM) dan Return On Asset (ROA) terhadap Return Saham Perusahaan Sektor Asuransi di Bursa Efek Indonesia. Skripsi UIN FEB Syarif Hidayatullah. Tidak Dipublikasikan

Hijriah, Almas. 2007. Pengaruh Faktor Fundamental dan Resiko Sistematik terhadap Harga Saham Properti di Bursa Efek Indonesia. Tesis Universitas Sumatera Utara. Medan.
Jogiyanto. 2014. Teori Portofolio dan Analisis Investasi. Edisi kedelapan. Yogyakarta. BPFE-Yogyakarta

Julduha, Nucifera dan Kusumawardhani, Indra. 2013. "Pengaruh Net Profit Margin, Current Ratio, Debt to Asset Ratio dan Tingkat Suku Bunga terhadap Beta Saham Syariah pada Perusahaan yang terdaftar di Jakarta Islamic Index". Jurnal Buletin Studi Ekonomi, Vol. 18 (2). pp. 144-152

Jusmaliani. 2008. Investasi Syariah: Implementasi Konsep pada Kenyataan Empirik, cet ke 1. Kreasi Wacana. Yogyakarta

Mediati, Sa'adah. 2008. Analisis Pengaruh Rasio Keuangan dan Total Aset terhadap Beta Saham Perbankan di Bursa Efek Indonesia. Tesis Universitas Sumatera Utara. Tidak Dipublikasikan

Natarsyah, Syahib. 2000. "Analisis Pengaruh Beberapa Faktor Fundamental dan Risiko Sistematik Terhadap Harga Saham (Kasus Industri Barang Konsumsi yang Go-Publik di Pasar Modal Indonesia)". Jurnal Ekonomi dan Bisnis Indonesia, Vol. 15 (3).

Priyatno, Dwi. 2008. Mandiri Belajar SPSS Untuk Analisis Data dan Uji Statistik. Mediakom

Rachmatika, Dian. 2006. Analisis Pengaruh Beta Saham, Growth Opportunities, Return On Asset dan Debt to Equity Ratio Terhadap Return Saham (Studi Komparatif Pada Perusahaan di BEJ yang Masuk LQ45 Tahun 2001-2004 Periode Bullish Dan Bearish). Tesis Magister Manajemen Universitas Diponegoro. Semarang. Tidak Dipublikasikan

Rodoni, A. dan Hamid, A., 2008. Lembaga Keuangan Syariah. Jakarta: Zikrul Hakim

Saribu, Ardin Dolok. 2011. Analisis Pengaruh Rasio Keuangan dan Total Asset Terhadap Harga Saham Dengan Beta Saham Sebagai Variabel Moderating (Studi Empiris Pada Perusahaan Perbankan Yang Terdaftar di Bursa Efek Indonesia). Tesis Universitas Sumatera Utara. Medan

Tandelilin, Eduardus, 1997. "Determinants of Systematic Risk: The Experience of Some Indonesia Common Stock". Kelola, No. 16 (4), pp. 101-114

Utomo, Welly. 2007. Analisis Pengaruh Beta Dan Varian Return Saham Terhadap Return Saham Studi Pada Perusahaan LQ 45 Di Bursa Efek Jakarta Periode Bulan 


\section{Jurnal Keuangan dan Perbankan | KEUANGAN}

Vol. 20, No.3, September 2016: 358- 368

Januari Tahun 2005 Sampai Dengan Bulan Desember Tahun 2005. Tesis Magister Manajemen Universitas Diponegoro. Semarang. Tidak Dipublikasikan

Santosa, Agus. 2011. Pengaruh Nilai Tukar Rupiah Per Dollar AS dan DER Terhadap Risiko Sistematis serta Return Saham pada Perusahaan Multinasional di Bursa Efek Indonesia. Tesis Universitas Udayana. Bali

Warsito, Irianto, Aryani, Y.A., dan Setiawan, D. 2003. "Pengaruh Pertumbuhan Aktiva, Rasio Profitabilitas, dan Beta Akuntansi terhadap Beta". Jurnal Bisnis \& Manajemen, Vol. 3 (2)
Widiastuti, Ekaningtyas dan Darmawati, Dwita. 2010, "Analisa Market Overreaction pada Saham LQ 45 di Bursa Efek Indonesia", Jurnal Fokus Ekonomi, Vol. 9 (3), pp. 128-202.

Widodo, Saniman. 2007. Analisis Pengaruh Rasio Aktivitas, Rasio Profitabilitas, dan Rasio Pasar, Terhadap Return Saham Syariah Dalam Kelompok Jakarta Islamic Index (JII) Tahun 2003 - 2005. Tesis. Universitas Diponegoro Semarang. Tidak Dipublikasikan 